\title{
Education about protection against solar radiation for teachers teaching young children: a contribution to promote school health
}

\author{
Educação sobre proteção contra radiação solar para professores da educação infantil: uma \\ contribuição para a promoção da saúde na escola
}

\author{
Gislaine Ricci Leonardi, Thais Mancini Banin, Fulvio Gabriel Corazza, Claudia Fegadolli \\ Instituto de Ciências Ambientais Químicas e farmacêuticas, Universidade Federal de São Paulo (UNIFESP), Diadema SP, \\ Brasil \\ Email: grleonardi@hotmail.com
}

\begin{abstract}
Skin cancer Primary prevention should focus young populations, using the school and teachers as strategic players. This paper describes results from a project aimed to educate kindergarten teachers in the Diadema municipality (metropolitan S Paulo) about photoeducation and sun exposure risks. The intervention was based on an investigation about teachers level of knowledge. Analysis revealed several gaps in knowledge topics - effects of skin tanning; sun exposure damage different than skin cancer; forms of sun protection, other than sunscreens; importance of sunscreen in childhood; types of solar radiation and their effects on human health; facts to be observed in the use of sunscreens. Based on the results of the first step, educational intervention was performed. The last step involved the evaluation of acquired knowledge. The collecting data technique was the Focal Group. Through content analysis, advances in knowledge and the acquisition of concepts were identified. The educational intervention was determinant for teachers knowledge especially regarding UVt radiation types and sun protection factors, but also revealed some pitfalls. In conclusion, short-term actions may be sufficient to transform some concepts but not enough to achieve all goals, especially the transformation of concepts related to cultural aspects, demanding greater daily educational investments.
\end{abstract}

Keywords: photoeducation, health, skin, school health, children

\begin{abstract}
Resumo
A prevenção primária do câncer da pele deve focar-se nas crianças, em especial, na escola e nos professores como elementos estratégicos. Este artigo descreve os resultados de um projeto de extensão de capacitação de professores de uma escola do município de Diadema (região metropolitana de São Paulo) para a educação sobre riscos da exposição solar e fotoproteção. A intervenção ocorreu a partir da investigação do conhecimento dos professores. Os resultados revelaram diversas lacunas em tópicos importantes - consequências do bronzeamento da pele; danos da exposição solar, além do câncer; proteção solar, além dos filtros solares; importância da proteção solar na infância; tipos de radiação e seus efeitos à saúde humana; critérios do uso de filtros solares. Com base nos resultados foi realizada intervenção educativa. Na última etapa realizou-se avaliação do conhecimento adquirido. O Grupo Focal e a análise de conteúdo, revelaram o impacto da intervenção educativa no conhecimento de professores, especialmente quanto aos tipos de radiação UV e fator de proteção solar, mas também alguns problemas. Em conclusão, a intervenção educativa de curta duração foi eficaz para transformar conceitos, mas não suficiente para atingir todos os objetivos, especialmente a transformação de conceitos ligados a aspectos culturais, os quais precisam de maior investimento educativo.
\end{abstract}

Palavras-chave: fotoeducação, saúde, pele, saúde escolar, crianças 


\section{Introduction}

Ultraviolet radiation is a risk factor for skin cancer and photoaging. The occurrence of skin cancer continues to grow primarily due to increased exposure to sunlight during childhood. Sun exposure usually occurs three times more frequently during childhood than in adult life, mainly due to the practice of recreational sports and outdoor activities. It is known that cumulative exposure to the sun during the first decades of life increases vulnerability to the harmful effects of radiation, which increases the risk of developing skin cancer in the future. $^{1-9}$

Therefore, primary prevention of skin cancer should target young children, and accordingly the school environment can be strategic, especially if it involves school teachers. Health education held by educators that are part of daily school routine has the advantage of involving professionals who already have good interaction with students. The school environment offers the possibility to exercise the practice of safe sun exposure, teaching children how to avoid periods of the highest ultraviolet radiation and also about the importance of having good habits of sun protection, such as wearing a hat and using an umbrella and sunscreens. ${ }^{10,11,12}$

Thus, health education in this area allows teachers to act as agents of change in children's attitudes related to health from the earliest stages of development with potential impact beyond the institution - including the community surrounding the school. For this, the promoter / teacher of healthy habits must have knowledge of the theoretical principles and also a conscious attitude towards its role in the formation of preventative habits. ${ }^{13}$

For these educational measures to achieve positive results, it is recommended that their design be adopted from the analysis of the real needs of the target population. ${ }^{14}$ Keeping this in view, the present study aimed to investigate the level of teachers' knowledge related to the education of school children in the municipality of Diadema (a metropolitan region of São Paulo), and intended to train school teachers to educate students on the risks of excessive exposure to sunlight as well as educate on photoprotection.

\section{Materials and methods}

The research and educational intervention were developed in a school for child education indicated by the Municipal Education Diadema-SP. All teachers working in schools $(\mathrm{n}=13)$ were invited and agreed to participate in the project. The project was approved by the Ethics Committee of the Federal University of São Paulo (UNIFESP) Process No. 332/11

The research occurred for ten months and developed into three stages. The first stage was a diagnosis on teachers' knowledge on the subject. Thirteen teachers

\section{Introdução}

A radiação ultravioleta é um fator de risco bem estabelecido para 0 câncer de pele e fotoenvelhecimento. A etiologia do câncer de pele está relacionada, principalmente, ao aumento da exposição ao sol, o que ocorre de maneira importante desde a infância, período em que os indivíduos são expostos por mais tempo. Na infância costuma ocorrer exposição solar três vezes mais frequentemente que na vida adulta, devido principalmente à prática de atividades recreativas e esportivas ao ar livre. Essa exposição ao sol durante as primeiras décadas de idade é cumulativa e aumenta a vulnerabilidade aos efeitos nocivos da radiação $0^{1-9}$.

Logo, a prevenção primária do câncer da pele deve ter como principal população-alvo as crianças e, nesse sentido, o espaço escolar pode ser estratégico, especialmente se envolver professores da própria escola. A educação em saúde realizada por educadores que fazem parte do cotidiano escolar tem a vantagem de envolver um profissional que já possui boa interação e convivência com os alunos. $\mathrm{O}$ ambiente escolar oferece a possibilidade de se exercitar a prática de exposição segura ao sol, ensinando as crianças como evitar os horários de maior radiação ultravioleta e também sobre a importância de se adotar bons hábitos de proteção solar, como chapéu ou guarda-sol e uso criterioso de filtros solares ${ }^{10,11,12}$.

Assim, a educação em saúde nesse campo possibilita que os professores atuem como agentes transformadores das atitudes ligadas à saúde a partir das fases mais precoces do desenvolvimento infantil, com possível impacto além da instituição, sobre a comunidade do entorno escolar. Para isso, o professor promotor de hábitos saudáveis deve possuir conhecimento dos princípios teóricos e uma atitude consciente do seu papel na formação de hábitos de prevenção ${ }^{13}$.

Para que as medidas educativas alcancem resultados positivos é recomendável que seu delineamento seja adotado a partir de análise das reais necessidades da população alvo ${ }^{14}$. Tendo isso em vista, o presente trabalho teve por objetivos investigar o nível de conhecimento dos professores de uma escola de educação infantil de um município da região metropolitana de São Paulo, bem como pretendeu capacitar os professores da escola para a educação sobre riscos do excesso de exposição solar e fotoproteção.

\section{Materiais e Métodos}

A pesquisa e intervenção educativa foram desenvolvidas no contexto de um projeto de Extensão universitária em uma escola de educação infantil indicada pela Secretaria Municipal de Educação Diadema-SP. Todos os professores que trabalham na escola $(n=13)$ foram convidados a participar do projeto e aceitaram após esclarecimento, leitura e assinatura do termo de consentimento livre e esclarecido. O projeto foi aprovado pelo Comitê de Ética em Pesquisa da Universidade Federal de São Paulo (UNIFESP) Parecer n ${ }^{0} 332 / 11$.

A pesquisa teve duração de dez meses, com desenvolvimento 
answered a questionnaire using a semi-quantitative analysis which identified knowledge gaps in terms of the risks of sun exposure and also photoprotection. This analysis provided confirmation needed for the content of the next stage - educational intervention. Therefore the results found in the first stage analyses were used to develop the educational material used in the second stage, which consisted of an informative pamphlet and presentation slides that were used in the teacher's group workshop. A period of 60 minutes was granted by the school to the speakers presenting the workshop to share information and answer questions about this subject. In the workshop the topics were addressed in oral presentation and concepts and doubts were freely discussed.

The researchers had another individual meeting with each teacher, reinforcing the main concepts through oral presentations and answering questions. At the end of the conversation, they provided an educational pamphlet to the teachers.

The third stage of the process was an evaluation of the results gathered from data collection through the use of the Focal Group (GF) technique.

GF is an investigation which a group of people is asked about their impressions, opinions and ideas about a certain topic, product or concept; a series of questions is posted and the group is encouraged to interact freely, conversing among themselves, about the proposed theme. It is not policy strategy, in which it is expected that participants $(\mathrm{P})$ feel more comfortable than when subjected to an interview, to provide their opinions from past experience because it is a more natural environment and assume the expression the point personal view, examples and memories may arise from the collective space. ${ }^{15-16}$

The GF was conducted with the support of a semi-structured interview attended by thirteen teachers and four researchers, lasting about 90 minutes. Two researchers took on the role of directing the group as a moderator (C) and assistant $(\mathrm{G})$ and two (F and $\mathrm{T}$ ) reported additional data for the transcription and analysis of the speeches, the identification of the participant and nonverbal expressions, and were responsible for the operation of the recording equipment. The guiding questions were based on the knowledge of the benefits and harms caused by the sun and on aspects related to sun protection. The data was fully transcribed and thematic content analysis, as Bardin (1977) ${ }^{17}$, was conducted according to the stages of pre-analysis, material exploration, and processing of results by inference and interpretation. Thus, through the fragmentation of words in sensible units, following the principle of grouping by similarity, themes and categories of analysis were revealed. Two researchers compiled, individually listed, and identified the issues, and disagreements were discussed seeking consensus. Excerpts from dialogues were chosen to exemplify each category. em três etapas. Na primeira etapa foi realizado diagnóstico sobre o conhecimento prévio dos professores a respeito do tema: os treze professores responderam a um questionário de perguntas abertas e fechadas cuja análise quali-quantitativa permitiu identificar lacunas do conhecimento a respeito de riscos de exposição solar e fotoproteção, o que subsidiou a elaboração do conteúdo da etapa seguinte, de intervenção educativa. A partir dos resultados, a segunda etapa consistiu na elaboração de material educativo (panfleto e slides), que foram utilizados em oficina em grupo com os professores. Foi concedido pela direção da escola um período de 60 minutos em uma das reuniões já existentes na instituição de ensino para que os pesquisadores realizassem a intervenção educativa e respondessem a questionamentos dos professores sobre $\mathrm{o}$ assunto. Na oficina os temas foram abordados em apresentação oral e discutiram-se livremente conceitos e dúvidas.

Além desse encontro, os pesquisadores tiveram outro encontro individual com cada um dos professores, reforçando os principais conceitos, por meio de exposição oral e esclarecimento de dúvidas. Ao término da conversa, deixaram um panfleto educativo em posse dos professores.

$\mathrm{Na}$ terceira etapa foi realizada avaliação do projeto como um todo e dos resultados da intervenção educativa, a partir de coleta de dados por meio da técnica do Grupo Focal (GF).

O GF é uma investigação na qual um grupo de pessoas é questionado sobre as suas impressões, opiniões e ideias sobre determinado tema, produto ou conceito; uma série de questões é lançada e o grupo é estimulado a interagir, conversando livremente entre si sobre a temática proposta. É estratégia não diretiva, a qual permite que os participantes sintam-se confortáveis para emitir suas opiniões a partir da experiência vivenciada, por se tratar de um ambiente mais natura ${ }^{15,16}$.

O GF, realizado com o apoio de um roteiro semi-estruturado, teve a participação de treze professores e quatro pesquisadores $(\mathrm{C}, \mathrm{F}, \mathrm{G}, \mathrm{T})$ e duração de cerca de 90 minutos. Dois pesquisadores assumiram o papel de dirigir o grupo como moderador $(C)$ e assistente $(\mathrm{G})$ e dois $(\mathrm{F}$ e $\mathrm{T})$ registraram dados complementares para a transcrição e análise das falas, como a identificação do participante $(\mathrm{P})$ e expressões não-verbais, além de terem sido responsáveis pela operação do equipamento de gravação. As questões norteadoras se basearam no conhecimento acerca dos efeitos da exposição ao sol, sobre aspectos ligados à proteção solar e na avaliação do processo de desenvolvimento do projeto pelo grupo. Os dados foram transcritos integralmente e a análise temática de conteúdo, segundo Bardin $(1977)^{17}$, foi conduzida segundo as etapas de pré-análise, exploração do material, tratamento dos resultados por inferência e interpretação. Assim, por meio da fragmentação das falas em unidades de sentido, seguiu-se ao seu agrupamento pelo princípio de similitude, o que revelou temas e categorias de análise. Dois pesquisadores compilaram, individualmente, os temas e enunciados identificados e as divergências foram discutidas buscando-se o consenso. Foram escolhidos trechos de falas para exemplificar cada categoria. 


\section{Results and discussion}

In the diagnostic stage of knowledge, it was determined that of all the school teachers $(n=13)$ only one considered that untanned skin is healthy, while others responded that the color does not matter or that tanned skin has a more healthy appearance. Only four teachers reported skin aging and nine cited skin cancer as caused by the sun. For six teachers, the best form of sun protection was the use of sunscreens daily, but the search for shade and use of sunscreen in summer were also cited. Only two teachers cited the clothing as a form of protection. Two teachers could identify childhood as the period of greatest vulnerability to the cumulative action of the sun.

Most participants (ten) had no knowledge about the types of solar radiation, about types of sunscreens, and about the information contained on product packaging. Thus, it was found that the educational interventions should approach the following points:

- Association between the appearance of tanned skin and health;

- Possible damage of sun exposure for the skin, as skin cancer

- Forms of sun protection, as well as sunscreens;

- Importance of sun protection in childhood;

- Types of solar radiation and the effects on human health;

- Facts to be observed in the use of sunscreens.

\section{Resultados e Discussão}

$\mathrm{Na}$ etapa de diagnóstico do conhecimento, identificou-se que, de todos os professores da escola $(n=13)$, apenas um considerou que a pele não bronzeada representa saúde, enquanto que os demais responderam que a cor não importa ou que a pele bronzeada tem aparência mais saudável. Apenas quatro professores relataram o envelhecimento da pele como um malefício provocado pelo sol e nove citaram o câncer de pele. Para seis professores, a melhor forma de proteção solar é a utilização de filtros diariamente, mas a busca por sombra e uso de filtro solar no verão também foram citados. Apenas dois professores citaram as roupas como forma de proteção. Dois professores citaram a infância como a fase de maior vulnerabilidade à ação cumulativa do sol.

A maior parte dos participantes (dez) não tinha conhecimentos sobre os tipos de radiação solar, sobre os tipos de fotoprotetores e sobre as informações presentes nos rótulos dos produtos.

Assim, identificou-se na que a intervenção educativa deveria abordar os seguintes conteúdos:

- associação existente entre a aparência de pele bronzeada e a saúde;

- possíveis danos da exposição solar à pele, além do câncer de pele;

- formas de proteção solar, além de produtos com filtros solares;

- importância da proteção solar na infância;

- tipos de radiação solar e seus efeitos à saúde humana;

- critérios a serem observados no uso de filtros solares.

\section{Focal group}

The thematic content analysis resulted in three classes and seven thematic categories.

\section{Grupo focal}

A análise temática de conteúdo resultou em três classes temáticas e sete categorias.

Table 1 / Tabela 1 - Themes and categories that emerged from the dialogues of the participants / Temas e categorias que emergiram das falas dos participantes do estudo.

\begin{tabular}{|c|c|}
\hline Themes / TEMAS & CATEGORIES / CATEGORIAS \\
\hline $\begin{array}{l}\text { The sun and the } \\
\text { effects of sun } \\
\text { exposure / O sol e } \\
\text { os efeitos da } \\
\text { exposição solar }\end{array}$ & $\begin{array}{l}\text { - Skin tanning / Bronzeamento da pele } \\
\text { - Consequences of solar radiation / Consequências da radiação solar }\end{array}$ \\
\hline $\begin{array}{l}\text { Photoprotection / } \\
\text { Fotoproteção }\end{array}$ & $\begin{array}{l}\text { - Sunscreen (Product) /Protetor solar (produto) } \\
\text { - Forms of Protection (attitudes) / Formas de proteção (atitudes) } \\
\text { - Protection in childhood / Proteção na infância }\end{array}$ \\
\hline $\begin{array}{l}\text { University - } \\
\text { Community } \\
\text { Projects / } \\
\text { Projetos } \\
\text { Universidade- } \\
\text { Comunidade }\end{array}$ & $\begin{array}{l}\text { - Be heard and learn from researchers / Ser ouvido e aprender com } \\
\text { os pesquisadores } \\
\text { - The return of research results to the community / O retorno dos } \\
\text { resultados da pesquisa à comunidade }\end{array}$ \\
\hline
\end{tabular}


The following categories, with examples from dialogues, emerged in each topic, forming units of analysis.
A seguir são apresentadas categorias que emergiram em cada tema com exemplos de falas que se constituíram em unidades de análise.

Table 2 / Tabela 2 - Analysis Units (examples) of the category "Skin Tanning" / Unidades de Análise (exemplos) da categoria "Bronzeamento da pele"

\begin{tabular}{|c|l|}
\hline \multirow{3}{*}{$\begin{array}{c}\text { Skin tanning / } \\
\text { Bronzeamento da } \\
\text { pele }\end{array}$} & $\begin{array}{l}\text { P11: "whoever wants to tan their skin at the beach, needs to do it } \\
\text { from 10 a.m to 2 p.m. Under the umbrella, with enough protection, } \\
\text { so we can be pretty good." / P11: "Mas quem quer pegar um bronze na } \\
\text { praia, precisa ser das 10 às 14. Debaixo do guarda-sol, com bastante } \\
\text { proteção, para ficar bem bonita." } \\
\text { P7: " Before it was necessary to be tanned. The media asked that. } \\
\text { You had to spend the summer with bikini little mark. Because it was } \\
\text { terrible you be white! Not now, thank God, being white is a normal } \\
\text { thing, healthy, is not something from another world. I can continue } \\
\text { with my color, with my pale white skin . I take sun, use sunscreen, } \\
\text { tan my skin a little, but I don't have more than I need than I had } \\
\text { before to have a fully tanned skin ... ". / P7: "Antes era necessário ser } \\
\text { bronzeada. A mídia pedia isso. Você tinha que passar o verão com } \\
\text { marquinha de biquíni. Porque era terrível você ser branca! Agora não, } \\
\text { graças a Deus, ser branca é uma coisa normal, saudável, não é coisa do } \\
\text { outro mundo. E eu posso continuar com a minha cor, com a minha tez } \\
\text { pálida e branca numa boa. Tomo Sol, coloco protetor, me bronzeio um } \\
\text { pouquinho mais, mas eu nunca vou precisar ter aquela necessidade que eu } \\
\text { tinha antes, de ter uma pele totalmente bronzeada...”. }\end{array}$ \\
\hline
\end{tabular}

There is a belief among the research subjects, that the negative consequences of sun exposure occur only at times considered "forbidden", and a misconception that tanning is safe. Even though it is now socially acceptable to keep the skin without tanning, participants did not associate the tanning with cell damage. Although they reported that white and pale skin is acceptable, they seem to believe that it is better to have tanned skin. Beauty was associated with fair skin by the early twentieth century, and people regularly used hats, gloves, and umbrellas. Individuals with tanned skin belonged to a lower social class linked to manual labor, as sailors, farmers, fishermen, etc. However, after World War I there was an inversion of values. The very white skin became associated with work in offices and factories, and with people who had no time to be exposed to the sun. Those with higher purchasing power had free time to enjoy the sunshine of the field or the beach ${ }^{18}$. This trend, the result of European heritage, stemmed from the perception that tanned skin was associated with higher social status and a healthier lifestyle ${ }^{21}$.

However, tanned skin is synonymous with skin assaulted by the sun, and when excessive sun exposure occurs, even in times where the sun is milder, harm to skin health can occur ${ }^{19,20,21}$.

Beyond tanning, the subjects recognized the real ben-
Existe a crença, entre os sujeitos da pesquisa, de que as consequências negativas da exposição solar ocorrem apenas em horários considerados "proibidos" e a ideia errada de que o bronzeamento é seguro. Mesmo considerando que, atualmente, existe aceitação social para que se mantenha a pele sem bronzeamento, os participantes não associam o bronzeado a dano celular. Expressam que a cútis branca e pálida é aceitável, mas parece estar implícita a ideia de que é melhor ter a pele bronzeada. Essa crença está ligada à cultura do bronzeado construída historicamente no Brasil. Sabe-se que até o princípio do século XX, bonito era ter pele clara. Para isso as pessoas utilizavam chapéus, luvas, sombrinhas. Os indivíduos de pele bronzeada pertenciam a uma classe social inferior ligada a trabalhos manuais, como marinheiros, agricultores, pescadores. Porém, depois da I Guerra Mundial houve uma inversão de valores. A palidez passou a ser associada ao trabalho em escritórios e fábricas e às pessoas que não tinham tempo para se expor no sol. Aquelas de maior poder aquisitivo tinham tempo livre para aproveitar o sol do campo ou da praia $^{18}$. Essa tendência, fruto de herança europeia, decorria da percepção de que a pele bronzeada estava associada a um status social mais elevado, bem como a uma vida mais saudável ${ }^{21}$.

No entanto a pele bronzeada é sinônimo de agressão pelo sol e, quando ocorre exposição solar excessiva, mesmo nos horários onde o sol é mais ameno, podem ocorrer malefícios para a saúde cutânea ${ }^{19,20,21}$. 
efits of sun exposure, and the effects of vitamin D on bone formation, but not on the prevention of autoimmune diseases ${ }^{22}$. Sunlight was also associated with an individual's state of welfare and happiness.

As a negative consequence of excessive exposure to the sun, the issue of aging skin emerged from the dialogues, demonstrating the effectiveness of the educational intervention since the initial diagnostic step when this knowledge was partially identified.
Além do bronzeamento, os sujeitos reconhecem os reais benefícios do sol, como os efeitos da vitamina $\mathrm{D}$ sobre a formação óssea, mas não sobre a prevenção de doenças auto-imunes ${ }^{22}$. Associam, também, a luz solar ao estado de bem- estar e alegria dos indivíduos.

Como consequência negativa da exposição excessiva ao sol, emergiu das falas a questão do envelhecimento cutâneo, mostrando a eficácia da intervenção educativa, uma vez que na etapa de diagnóstico inicial esse conhecimento foi parcialmente identificado.

Table 3 / Tabela 3 - Analysis Units (examples) of the category "Consequences of solar radiation" / Unidades de Análise (exemplos) da categoria "Consequências da radiação solar"

\begin{tabular}{|c|c|}
\hline $\begin{array}{l}\text { Consequences of } \\
\text { solar radiation / }\end{array}$ & $\begin{array}{l}\text { P6: "The sun, it helps in bone formation [...], is vitamin D, vitamin } \\
\text { D is fixed." / P6: "O sol auxilia na formação óssea [...], fixa vitamina } \\
\text { D". } \\
\text { P7: "I think another thing that is important from the Sun, is the joy } \\
\text { that provides . Because I think that without the sun, the light, the } \\
\text { heat, everything is very depressing." / P7: "Ah, eu acho que o } \\
\text { importante do Sol é a alegria. Porque eu acho que sem o Sol, a luz, esse } \\
\text { calor, fica tudo muito depressivo". } \\
\text { P1: "I think the effects end up coming later. The issue of aging } \\
\text { skin [...] you realize, a little later you realize, pigmentation marks, } \\
\text { they are more frequent [...] the issue of skin cancer. This lack of } \\
\text { protection that ends up causing discomfort afterwards. " / P1: "Eu } \\
\text { acho que os efeitos acabam vindo mais tarde. A questão do } \\
\text { envelhecimento da pele [...] um pouquinho mais tarde você percebe as } \\
\text { manchas, que elas são mais frequentes [...] a questão do câncer de pele. } \\
\text { Essa falta de proteção acaba gerando esse mal estar depois". } \\
\text { P7: I learned that the UVB is responsible for burn, it burns us } \\
\text { superficially, causing red skin. And that UVA causes the most } \\
\text { damage, because it is inside, on the inside of the skin, you will get } \\
\text { to age, and will manifest with age too. So the UVB is the part that } \\
\text { people see that burned and UVA also burn but you do not see, that } \\
\text { is the inside of the skin. " / P7: Eu aprendi que o UVB deixa a pele } \\
\text { queimada, que queima superficial, que deixa vermelho, que atua mais } \\
\text { nessa parte visível. E que o UVA é a que causa maior dano, porque ela } \\
\text { atua dentro, na parte de dentro da pele, que você vai levar para a idade, e } \\
\text { vai se manifestar com a idade também. Então o UVB é essa parte que a } \\
\text { gente vê que queimou e a UVA queima mas você não vê, é a parte de } \\
\text { dentro da pele". }\end{array}$ \\
\hline
\end{tabular}

The knowledge acquired through the study course of action regarded the meaning of the acronyms UVA and UVB. It was learned that UVB radiation causes redness and pain, but that UVA can also cause damage, such as skin aging and skin cancer.

Indeed, UVA radiation, less energetic and more abundant, has the characteristic to penetrate deeper into the skin and may be referred to as "silent" as it causes no erythema or burns and eventually leads to skin pigmentation promoting tan. The adverse effects range from
O conhecimento mais evidentemente adquirido por meio da intervenção foi a respeito do significado das siglas UVA e UVB. Aprenderam que a radiação UVB causa a vermelhidão e dor, mas que a UVA também pode causar danos, como envelhecimento da pele e câncer de pele.

De fato, a radiação UVA, menos energética e mais abundante, tem a característica de penetrar mais profundamente na pele, não provocando queimaduras ou eritema, podendo ser designada "silenciosa". Acaba induzindo a pigmentação da pele, 
the possibility of damage to the peripheral vascular system to the induction of skin cancer (based on skin tone, the time and the frequency of exposure) and also influences the formation of free radicals $23,24,25,26$. The more energetic UVB penetrates the surface layers of the skin, often causing sunburn ${ }^{27}$. It is also responsible for the premature aging of cells. The greater the frequency and intensity of exposure to UVB radiation, the higher the probability of damage ${ }^{28,29}$

The importance of this knowledge is related to the choice of particular sunscreens, as their labeling is often unclear as to the extent of protection that they propose to provide. promovendo o bronzeado. Os efeitos adversos vão desde a possibilidade de danos para o sistema vascular periférico até a indução de câncer da pele, dependendo do tom da pele, do tempo e da frequência de exposição. Indiretamente os raios UVA também estimulam a formação de radicais livres ${ }^{23,24,25,}$ ${ }^{26}$. A radiação UV-B, mais energética, penetra as camadas superficiais da pele, frequentemente provocando queimaduras solares ${ }^{27}$. É, também, responsável pelo envelhecimento prematuro das células e, quanto maior a frequência e a intensidade de exposição à radiação UV-B, maior é a probabilidade de danos ${ }^{28,29}$.

A importância desse conhecimento está especialmente ligada à escolha de filtros solares, que muitas vezes não trazem claro na rotulagem do produto o tipo de proteção a que se propõem.

Table 4 / Tabela 4 - Analysis Units (examples) of the category "Sunscreen" / Unidades de Análise (exemplos) da categoria "Protetor solar (produto)"

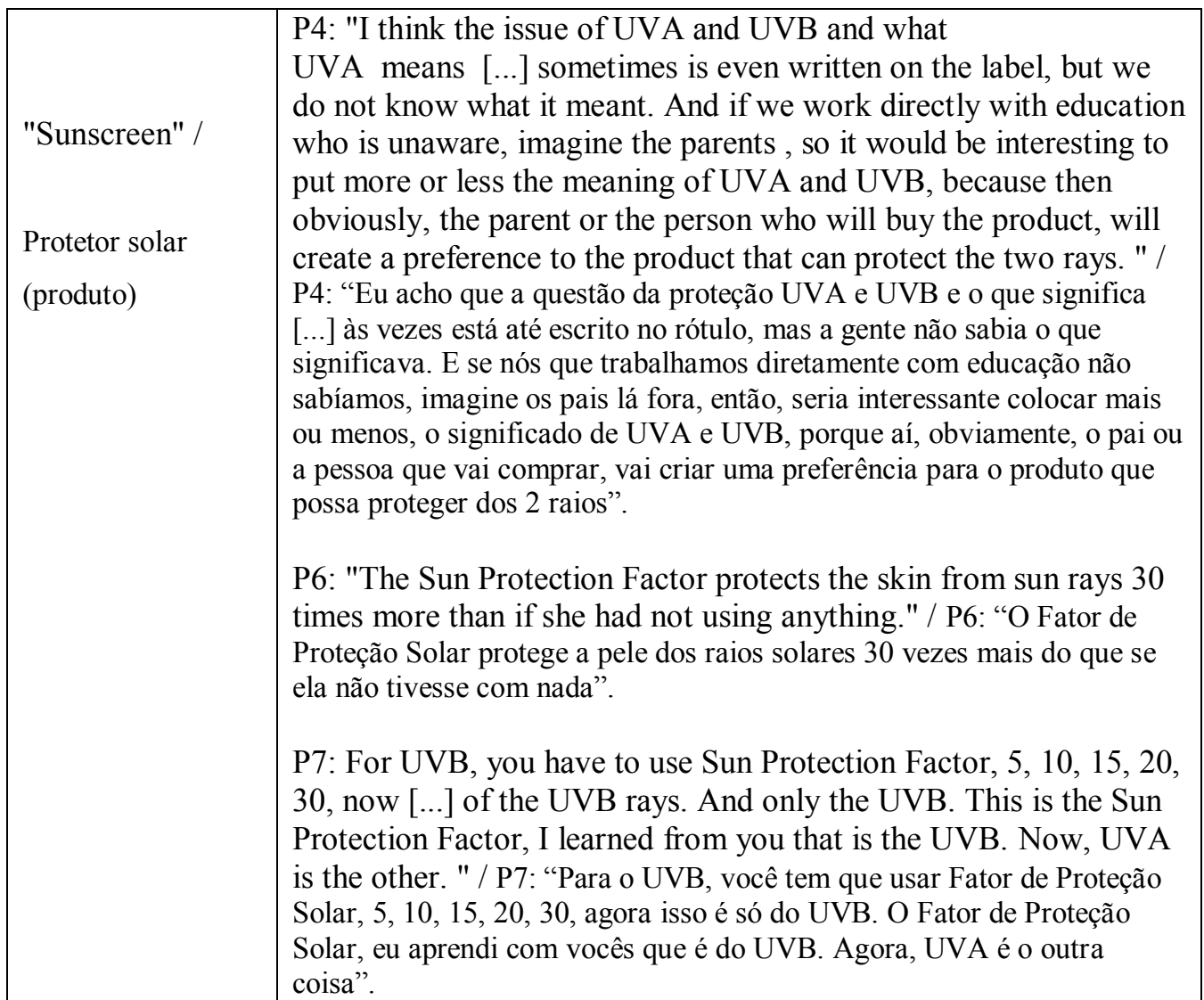

The dialogues illustrate the impact of photoeducation, showing that the intervention provided subject to the understanding of the mechanism of protection of products. As forms of protection, clothing, accessories and shade were also identified.

Places to look for shade when exposed to the sun were considered important by the teachers, but more emphasis was given to the use of sunscreens. There is a greater concern with using sunscreen on face, not only for aesthetics, but as the area of greatest exposure.
As falas ilustram o impacto da fotoeducação, mostrando que a intervenção proporcionou aos sujeitos o entendimento sobre o mecanismo de proteção dos produtos. Como forma de proteção, também foram identificadas as roupas, acessórios e sombra.

Os professores consideram importante procurar por locais de sombra quando se expõem ao sol, porém foi dada maior ênfase ao uso de fotoprotetor. Existe uma maior preocupação em utilizar fotoprotetor no rosto, não só por questão estética, mas por ser a área de maior exposição. 
However, the need for reapplication of the product was not mentioned, nor the amount that should be used in each region of the body. This suggests that this concept was important but not well settled.
No entanto não foram mencionadas nem a necessidade de reaplicação do produto, nem a quantidade que deve ser utilizada em cada região do corpo. Isso sugere que esse conceito não foi bem sedimentado, embora importante.

Table 5 / Tabela 5 - Analysis Units (examples) of the category "Forms of Protection (attitudes-“" / Unidades de Análise (exemplos) da categoria "Formas de proteção (atitudes)"

\begin{tabular}{|c|c|}
\hline $\begin{array}{l}\text { "Forms of } \\
\text { Protection } \\
\text { (attitudes)" / } \\
\text { Formas de proteção } \\
\text { (atitudes) }\end{array}$ & $\begin{array}{l}\text { P5: "I use sunscreen daily but only when I leave home, not when I } \\
\text { stay inside at home. That means that if hanging the washed } \\
\text { laundry and exposed to the sun, I will not have my skin pretected. " } \\
\text { P5: "Eu uso fotoprotetor diariamente, mas só quando eu saio de } \\
\text { casa. Quando eu vou ficar em casa eu não uso fotoprotetor. Então, } \\
\text { se eu estiver em casa e for estender uma roupa no varal, vou ter } \\
\text { contato com o sol, sem proteção na pele } \\
\text { P1: "But we end up focusing more on the face [...]. But it is a } \\
\text { matter of habit, it is a question of face we protect. . / P1: "Mas a } \\
\text { gente acaba focando mais na questão do rosto [...]. Mas é questão de } \\
\text { hábito, é mais a questão da face mesmo que a gente protege". } \\
\text { P1: "So we try to avoid the hours of strong sun. In the afternoon } \\
\text { we try to go a shade, we ask to children look for shade." / P1: "E aí } \\
\text { a gente procura, evitar a hora do Sol forte. A tarde a gente procura ir para } \\
\text { uma sombra, mando as crianças procurarem sombra". }\end{array}$ \\
\hline
\end{tabular}

Protection during childhood was not explained by the concept of the subject cumulative effect related to exposure. There were only reports that child care in this regard should be increased due to the fragility of the skin at this age, as the units of analysis illustrate the category "protection in childhood." This concept may be too complex to be grasped in a short educational intervention.
Quanto à proteção durante a infância não foi explicitado pelos sujeitos o conceito do efeito cumulativo relacionado à exposição. Houve apenas relatos de que os cuidados com as crianças deve ser maiores devido à fragilidade da pele nessa faixa etária, conforme ilustram as unidades de análise da categoria "proteção na infância". Talvez esse conceito seja complexo para ser apreendido em uma intervenção educativa de curta duração.

Table 6 / Tabela 6 - Analysis Units (examples) of the category "Protection in childhood" / Unidades de Análise (exemplos) da categoria "Proteção na infância"

\begin{tabular}{|l|l|}
\hline Protection & $\begin{array}{l}\text { P7: "I think we have to invest in the child's, skin is very sensitive, a } \\
\text { baby on the beach, have to be very careful." / P7: "Eu acho que a gente tem } \\
\text { in } \\
\text { que investir na criança, a pele é muito sensível, um bebê, na praia, tem que } \\
\text { tomar muito cuidado". }\end{array}$ \\
$\begin{array}{l}\text { Proteção na } \\
\text { infância }\end{array}$ & $\begin{array}{l}\text { P1: "The child? The skin is more sensitive. " / P1: "A criança? A pele é } \\
\text { mais sensível". }\end{array}$ \\
\hline
\end{tabular}


It is observed that the importance of care in childhood is understood according to common sense of the sensitive skin of the child. Although it is mentioned within the category "consequences of solar radiation" that aging is perceived in the future, this concept does not seem to be transposed to the effects of the sun in childhood and its relation to skin cancer.

Finally the GF' participants were encouraged to evaluate the development of the project, resulting in two categories presented in Tables 7 and 8 .
Observa-se que a importância do cuidado na infância é compreendida segundo o senso comum, pela pele sensível da criança. Embora na categoria "conseqüências da radiação solar" seja mencionado que o envelhecimento é percebido no futuro, esse conceito não parece ser transposto para os efeitos do sol a partir da infância e sua relação com o câncer de pele.

Por fim os participantes do GF foram estimulados a avaliar o desenvolvimento do projeto, resultando em duas categorias apresentadas nos quadros 7 e 8 .

Table 7 / Tabela 7 - Analysis Units (examples) of the category "Being heard and learn from the researchers' / Unidades de Análise (exemplos) da categoria "Ser ouvido e aprender com os pesquisadores"

\begin{tabular}{|c|c|}
\hline $\begin{array}{l}\text { Be heard and } \\
\text { learn from } \\
\text { researchers / } \\
\text { Ser ouvido e } \\
\text { aprender com } \\
\text { os } \\
\text { pesquisadores }\end{array}$ & $\begin{array}{l}\text { P3: So, take a moment even to us, that we getting more comfortable to } \\
\text { ask questions / P3: Então, ter um momento mesmo só nosso, faz a gente } \\
\text { ficar mais à vontade para fazer perguntas } \\
\text { P5: "Just the fact of having had this return, having answered the } \\
\text { questions of the people, I think most of us did not know the meaning of } \\
\text { UVA, UVB, what was the difference between one and another, the } \\
\text { question of SPF .. / P5: "Só o fato de ter tido esse retorno, de ter respondido } \\
\text { as dúvidas da gente. Eu acho que a maioria de nós não sabia o significado de } \\
\text { UVA, de UVB, qual era a diferença entre um e outro, a questão do FPS.. } \\
\text { P3: "It has rich information, [...] we believed that we knew of } \\
\text { protection, in fact, we knew nothing. [...] / P3: "Passou informação rica, } \\
\text { [...] todo mundo acreditava que sabia da proteção, mas não sabia nada. [...] }\end{array}$ \\
\hline
\end{tabular}

Initially considered not important for research subjects, the proposed topic to be explored provided relevant targeted educational activities. The project highlighted important gaps in knowledge about photoprotection and that educational approaches to the topic are justifiable and necessary.

The project also stressed the importance of returning the results of academic work to the partner community. The absence of this return may cause damage to the image of university extension and hinder the study goals.
Considerado inicialmente banal pelos sujeitos da pesquisa, o tema proposto, ao ser explorado, mostrou-se relevante como alvo de ações educativas. O projeto evidenciou importantes lacunas no conhecimento acerca da fotoproteção e que abordagens educativas sobre o tema são justificáveis e necessárias.

Ressaltou-se a importância de retornar os resultados do trabalho acadêmico para a comunidade parceira, cuja ausência traz prejuízos à imagem de instituição universitária e frustra os objetivos extensionistas.

Table 8/ Tabela 8 - Analysis Units (examples) of the category "The return of research results to the community" / Unidades de Análise (exemplos) da categoria "O retorno dos resultados da pesquisa à comunidade"

\begin{tabular}{|l|l|}
\hline $\begin{array}{l}\text { The return } \\
\text { of research } \\
\text { results to } \\
\text { the } \\
\text { community/ }\end{array}$ & $\begin{array}{l}\text { P5: [...] this return was important and we did not have this back in other } \\
\text { studies in other work carried out here, we had no such returns in other } \\
\text { studies. " / P5: [...] esse retorno para gente foi importante e não aconteceu em } \\
\text { outras pesquisas, em outros trabalhos que foram realizados aqui. A gente não } \\
\text { teve esse retorno em outras pesquisas". } \\
\text { dos } \\
\text { resultados da } \\
\text { pesquisa à } \\
\text { comunidade }\end{array}$ \\
$\begin{array}{l}\text { P12: many projects come to us, teachers, and almost none of them have } \\
\text { continuity. So it's very nice seeing you came and continued, now you are } \\
\text { here, giving a continuity, giving up maybe a bridge to continue next } \\
\text { year, that's very good. " / P12: Chegam muitos projetos até nós, professores, } \\
\text { e quase nenhum deles, tem continuidade. Então, é muito agradável, ter visto } \\
\text { que vocês vieram, continuaram, e vocês estão aqui agora, dando uma } \\
\text { continuidade, dando até, quem sabe, uma ponte pra continuar no ano que vem, } \\
\text { pra estender isso, muito bom". }\end{array}$ \\
\hline
\end{tabular}


The importance of returning the results of academic work to the social environment in which they are developed was discussed by Peixoto and Patzlaff ${ }^{30}$. The authors exposed possibilities and argued that activities that return knowledge to the community can be proposed and agreed at the beginning of the research, but should be flexible to allow for the inclusion of unforeseen demands. It appears that the act of knowledge return is ethical and pleases the community in which the work originates, making the community a partner in future initiatives.

\section{Conclusion}

The work shows the feasibility of university extension as a means of transforming social reality, articulated teaching and research way. It was found that the promotion of health, with a focus on protecting the skin, should seek the reformation of beliefs about sun protection and tanning among the population. Short durations of such activities may not be sufficient for the target population to absorb and incorporate concepts related to the cultural aspects of sun exposure. A greater investment in education adapted into daily school life is needed.

\section{Acknowledgment}

We thank PROEX UNIFESP for assistance with this project.

\section{Conflict of Interests}

We declare no conflicts of interest on the part of the authors.
A importância de retornar os resultados do trabalho acadêmico para o meio social no qual este se desenvolve é discutida por Patzlaff e Peixoto ${ }^{30}$. Os autores expõem possibilidades e argumentam que as atividades de retorno do conhecimento à comunidade podem ser propostas e acordadas no início da pesquisa, devendo ser flexíveis para que possibilitem a inclusão de demandas não previstas. Verifica-se que o ato de retornar, além de ético, agrada a comunidade na qual o trabalho se origina, tornando-a parceira de futuras iniciativas.

\section{Conclusão}

O trabalho desenvolvido mostra a viabilidade da extensão universitária como meio transformador da realidade social, de maneira articulada ao ensino e à pesquisa. Verificou-se que a promoção de saúde, com foco na proteção da pele, deve buscar a reconstrução de crenças sobre proteção solar e bronzeamento junto à população e que atividades de curta duração como essa podem não ser suficientes para que a população alvo absorva e incorpore todos os conceitos, os quais devem ser trabalhados na culturalmente, de maneira transversal e cotidiana no contexto escolar.

\section{Agradecimentos}

Agradecemos a PROEX da UNIFESP pelo auxilio ao Projeto.

\section{Conflito de Interesses}

Declaramos que não há conflitos de interesse por parte dos autores do artigo. 


\section{References/ Referências}

1. Collins DCA, Kearns RA, Mitchell H. An integral part of the children's education: placing sun protection in Auckland primary schools. Health and Place 2006; 12: 436448.

2. Giles-Corti B, et. al. Creating SunSmart schools. Health Education Research 2004; 19 (1): 98-109.

3. Costa FB, Weber MB. Avaliação dos hábitos de exposição ao sol e de fotoproteção dos universitários da Região Metropolitana de Porto Alegre, RS. An Bras Dermatol 2004; 79: $149-55$.

4. Lupton D, Gaffney D. Discourses and practises related to sun tanning and solar protection among young Australians. Health Education Research 1996; 11: 147-159.

5. Geller AC, Colditz G, Oliveria S, Emmons $\mathrm{K}$, Jorgensen C, Aweh GN. et al. Use of sunscreen, sunburning rates, and tanning bed use among more than 10000 US children and adolescents. Pediatrics 2002; 109: 1009-1014.

6. Gritz ER, et al. An intervention for parents to promote preschool children's sun protection: effects of Sun Protection is Fun! Preventive Medicine 2005; 41 (2): 357-366

7. Livingston PM, White VM, Ugoni AM, Borland R. Knowledge, attitudes and self-care practices related to sun protection among secondary students in Australia. Health Education Research 2001; 16: 269-278.

8. Lowe JB, Borland R, Stanton WR, Baade P, White V, Balanda KP. Sun-safe behavior among secondary school students in Australia. Health Education Research 2000; 15(3): 271-81.

9. Rodrigo FG, et. al. O sol, a praia e a pele das crianças. Acta Pediatr Port 2011; 42(2): 717.

10. Basting RT, et al. A importância do professor como agente multiplicador de Saúde Bucal. Revista da ABENO 2004; 6(2): 102-108. http://www.abeno.org.br/ckfinder/userfiles/ files/revista-abeno-2006-2.pdf\#page $=6$ (acessado em: 14.05. 2012).
11. França-Botelho AC, Silva LR. Proteção solar para crianças: estudo preliminar sobre conhecimentos e atitudes dos pais. Ciência \& Saúde 2011; 4(1): 2-6. http://revistaseletronicas.pucrs.br/ojs/index.php/faenfi/ article/viewFile/8587/6624 (acessado em: 14.05.2012).

12. Noronha MI, Rodrigues MA. Saúde e bemestar de crianças em idade escolar. Esc Anna Nery 2011; 15(2): 395-401. http://www.scielo.br/pdf/ean/v15n2/v15n2a24.pdf (acessado em: 13.05.2012).

13. Davanço GM, Taddei JAAC, Gaglianone CP. Conhecimentos, atitudes e práticas de professores de ciclo básico, expostos e não expostos a curso de educação nutricional. Rev Nutr 2004; 17(2): 177-84.

14. Iervolino AS, Pelicioni MCF. Capacitação de professores para a promoção e educação em saúde na escola: relato de uma experiência. Rev Bras Cresc Desenv Hum 2005; 15(2): 99-110.

15. Fleck MPA, Chachamovich E, Trentini CM. Projeto WHOQOL-OLD: método e resultados de grupos focais no Brasil. Revista de Saúde Pública 2003; 37(6): 793-799.

16. Marshall C, Rossman GB. (1999). Designing qualitative research. Thousand Oaks, CA: Sage Publications, Inc

17. Bardin, L. Análise de conteúdo. Lisboa: Edições 70, 1977.

18. Velasco De Paola MVR. Importância da fotoproteção. Revista de Cosmiatria e Estética 1999: 7(4): 5-7.

19. Lim HW, James WD, Rigel DS, Maloney ME, Spencer JM, Bhushan R. Adverse effects of ultraviolet radiation from the use of indoor tanning equipment: Time to ban the tan. J Am Acad Dermatol 2011; 64(5): 893902.

20. Lazovich D, Forster J. Indoor tanning by adolescents: prevalence, practices and policies. European Journal of Cancer 2005; 41 : 20-27.
21. Sivamani RK, Crane LA, Dellavalle RP.The Benefits and Risks of Ultraviolet Tanning and Its Alternatives: The Role of Prudent Sun Exposure. Dermatol Clin 2009; 27: 149-154.

22. Marques,CDL.; Dantas,AT.; Fragoso,TS.; Duarte,ALBP. A importância dos níveis de vitamina D nas doenças autoimunes. Rev Bras Reumatol 2010;50 (1): 67-80.

23. Souza SRP. et al. Bronzeamento e risco de melanoma cutâneo: revisão da literatura Rev Saúde Pública 2004; 38(4): 588-98.

24. Velasco De Paola MVR, Ribeiro ME. Cosmetics \& Toiletries 1998; 10: 41.

25. Osterwalder U, Stanfield JW, Wang SQ. In vitro assessments of UVA protection by popular sunscreens available in the United States. Journal of the American Academy of Dermatology 2008; 59(6): 934-942.

26. Ruvolo Júnior, E. C. Proteção solar: comparação dos métodos de determinação por testes em humanos (in vivo), FDA, COLIPA SAA. Cosméticos On Line 1997; 19(105): 37-46.

27. Steiner D. Envelhecimento cutâneo. Cosmetics \& Toiletries 1995; 7(4): 29-32.

28. Hoffman K. et al. UV transmission measurements of small skin specimens with special quartz cuvettes. Dermatology 2000; 4: $307-$ 311 .

29. Norval M. The mechanisms and consequences of UV-induced immunosupression. Progress in Biophysics and Molecular Biology 2006; 1: 108-118.

30. Patzlaff RG, Peixoto AL. A pesquisa em etnobotânica e o retorno do conhecimento sistematizado à comunidade: um assunto complexo. Hist. cienc. saude-Manguinhos 2009 16 (1): 237-246. 